\title{
Research on the Correlation between Technological Innovation and Value Increase of Agricultural Companies Based on the Perspective of Company Life Cycle Theory
}

\author{
Zhu Yu ${ }^{1, *}$, Hua Zheng ${ }^{1}$ \\ ${ }^{1}$ Financial Management, Hohai University, West Focheng Road No.8, Nanjing, Jiangsu province, China
}

\begin{abstract}
Technological innovation should be given full play, and R\&D by agricultural companies should be given guidance. Because, for the purpose of increasing listed agriculture companies' value, promoting the industry's development, saving energy and resources in advanced agriculture productivity, such actions are of great significance. This paper takes agriculture companies listed in China's A-shares from 2015 to 2019 as research samples, and makes empirical research on the influence of technological innovation on the value of agriculture companies in different life cycle stages. It is found that technological innovation does not significantly increase the companies' value in their start-up and decline stages, while the situation becomes the opposite way in growth and maturity stages.
\end{abstract}

\section{1 introduction}

As the representative of China's advanced agriculture productivity, the listed agriculture companies undertake the important mission of promoting the agricultural industry's overall development and innovation in science and technology. Technological innovation is the inner impetus for the increase of company value ${ }^{[1]}$. However, for the listed agriculture companies, technological innovation means long cycles, high costs and low conversion rates. Therefore, the companies have laid more emphasis on product quality rather than technological innovation for a long time. Now, under the guidance of the national policy of Mass Entrepreneurship and Innovation Initiative, it has become an inevitable trend to push companies to transform and upgrade themselves, and increase their core competitiveness through innovation in science and technology.

Much research has been done on the correlation between innovation investment and company value in Chinese and foreign literature. Grilliches (1981) first proposed the relationship between technological innovation investment and company value. In his research, 157 American companies were taken as research samples and Tobin's Q was taken as the indicator for company value measurement. The conclusion suggests that innovation investment has a significant positive impact on company value ${ }^{[2]}$. Another research was done by Kingsley Olibe (2010) who used a smaller coverage of researched industries in which all manufacturing and service companies listed in the United States from 1990 to 2007 were taken as research samples. His empirical analysis also shows that innovation investment has a positive impact on company value ${ }^{[3]}$. Compared with the mature western capital market, the Chinese market still includes a lot of opportunistic operations. However, despite that, most Chinese researchers have gained the same conclusion. Cheng Hongwei et al. (2006) selected 96 listed companies and studied the relationship between their R\&D investment and performance using the multiple linear regression model. His research showed that the former positively influences the latter, but the influence decreases year by year ${ }^{[4]}$. Xie Wengang (2017) increased the number of samples. He studied 4,975 companies listed in China's A-shares from 2009 to 2015, and also concluded that innovation investment makes for the improvement of company performance ${ }^{[5]}$.

Reviewing the relevant studies, it can be found that in most of them, holistic listing companies are taken as research objects, and the ones studied listed agriculture companies accounted only for a tiny minority. Therefore, the previous conclusions may not be able to reveal the situation of Chinese listed agriculture companies. Besides, when studying the relationship between innovation investment and company value, the existing research mostly starts from government subsidies ${ }^{[6]}$ and cumulative effect ${ }^{[7]}$, and so on, and is seldom carried on based on the listed companies' different stages of life cycles. This paper takes listed agriculture companies as the research object, and uses the cash flow method to divide the company's life cycle into four stages, namely, the start-up stage, the growth stage, the maturity stage and the decline stage, and based on which, it makes empirical research on the relationship between innovation investment and company value for listed agriculture companies, using the multiple linear regression method. Based on the above, this paper also

* Corresponding author: zhuyuhhu@163.com 
proposes suggestions from the perspectives of government, companies and society. Therefore, this paper contains both practical and theoretical significance in path-finding of development for listed agriculture companies.

\section{Research design}

\subsection{Selection of variables}

\subsubsection{Explained variable}

Company value. Among all the methods to measure company value, Tobin's $\mathrm{Q}$ is one of the most frequently and widely used methods. Therefore, it is selected by this paper for company value measurement.

\subsubsection{Core explanatory variable}

Technological innovation. To study whether technological innovation has an impact on agricultural companies' development, this paper selects technological innovation as the explanatory variable and measures it with R\&D investment. In other words, the larger the amount of R\&D investment, the higher the intensity of technological innovation.

\subsubsection{Control variable}

a. Total assets. This paper measures the company's size with its total assets, which means, the more the company's total assets, the larger the company's size is and the higher the company's value will be.

b. Liquidity ratio. This paper measures the company's solvency with the ratio of its current assets and current liabilities, so as to control the solvency's impact on the company's value.

c. Growth rate of operation revenue. This paper measures the company's development ability with its growth rate of operation revenue, which is also an important factor affecting the company's value.

Table 1. Definitions of variables

\begin{tabular}{cccc}
\hline Variable types & Variable names & Variable symbols & Variable' explanations \\
\hline Explained variable & Company value & Tobin & Tobin's Q \\
Explanatory variable & Technological innovation & RD & R\&D investment \\
Total assets & Liquidity ratio & $\mathrm{A}$ & Agricultural company's total assets \\
Control variable & $\begin{array}{c}\text { Current assets/Current liabilities } \\
\text { Grow rate of operation } \\
\text { revenue }\end{array}$ & CR & $\begin{array}{c}\text { Operation revenue-operation revenue } \\
\text { of the previous year)/ operation } \\
\text { revenue of the previous year }\end{array}$ \\
\hline
\end{tabular}

\subsection{Samples and data}

All agricultural companies listed in China's A-shares from 2015 to 2019 are taken as research samples, while the ST companies are excluded, so do the samples with missing variable data. Then, the unbalanced panel is formed. Since dimensions are different for the selected variables, data of all variables are processed by min-max normalization. The data of this paper mainly comes from the CSMAR database, and the data software is Stata 16.0 .

$$
X_{\text {new }}=\frac{X_{i t}-X_{\min }}{X_{\text {max }}-X_{\text {min }}}
$$

\subsection{Model construction}

To study the influence of agricultural companies' R\&D investment on their value, the company value model is built.

$$
\begin{aligned}
& \text { Tobinq }_{i t}=\beta_{0}+\beta_{1} R D_{i t}+\beta_{2} A_{i t} \\
& +\beta_{3} C R_{i t}+\beta_{4} \text { Growth }_{i t}+\varepsilon_{i t}
\end{aligned}
$$

Where, the variable's subscript $i$ represents different agricultural companies, the $t$ represents different years, the $\beta_{0}$ represents the intercept term that does not change with individuals, the $\beta_{1}$ represents the estimated coefficient of explanatory variable, the $\beta_{2} \sim \beta_{4}$ represents the estimated coefficient of control variables, and the $\varepsilon_{i t}$ represents random errors.

\subsection{Division of company life cycle}

Bases on the cash flow method of Dickinson ${ }^{[8]}$, which defines the company's current stage of life cycle according to the combinations of its net cash flows generated from operations, investment, and financing, this paper divides the company's life cycle into four stages: the start-up stage, the growth stage, the maturity stage and the decline stage. 
Table 2. Division of company life cycle

\begin{tabular}{|c|c|c|c|c|}
\hline & Start-up stage & $\begin{array}{c}\text { Growth } \\
\text { stage }\end{array}$ & Maturity stage & $\begin{array}{c}\text { Decline } \\
\text { stage }\end{array}$ \\
\hline $\begin{array}{c}\text { Net cash flow from } \\
\text { operations }\end{array}$ & - & + & + & - \\
\hline $\begin{array}{c}\text { Net cash flow from } \\
\text { investments }\end{array}$ & - & - & - & - \\
\hline $\begin{array}{c}\text { Net cash flow from } \\
\text { financing }\end{array}$ & + & + & - & + \\
\hline
\end{tabular}

\section{Analysis on empirical results}

\subsection{Descriptive statistics}

Table 3 is the descriptive statistical results after variable normalization. From Table 3, it can be seen that a big difference exists between the companies' maximum value and minimum value, which indicates that company value varies greatly among sample agricultural companies. In terms of $R \& D$ research, despite that some companies make less R\&D investment in some years, their R\&D investment remains at a high level in general.
In terms of total assets, there is a big gap in total assets and sizes among sample companies. In terms of liquidity ratio, some companies have good solvency and high liquidity ratio, while liquidity ratios of some others are low. Judging from mean value, the normal asset-liability ratio is 2.54 , indicating good overall solvency. The big difference in operations revenue growth rate among sample companies indicates that some of them enjoy good development ability, while some others suffer from poor development ability and are in the decline stage, which may be related to the companies' life cycles.

Table 3. Descriptive statistical analysis results of variables

\begin{tabular}{|c|c|c|c|c|}
\hline Variables & Minimum & Maximum & Mean value & Standard deviation \\
\hline Tobinq & 0.90 & 7.98 & 2.21 & 1.01 \\
\hline$R D$ & 248861.41 & 570337330.20 & 43552654.23 & 8.78 \\
\hline$A$ & 287788533.30 & 32734965600.00 & 3373160513.00 & 3903644876.00 \\
\hline CR & 0.15 & 27.91 & 2.54 & 3.43 \\
\hline Growth & -2.78 & 69.81 & 1.68 & 5.97 \\
\hline
\end{tabular}

Table 4. Normalized descriptive statistical analysis results of variables

\begin{tabular}{|c|c|c|c|c|}
\hline Variables & Minimum & Maximum & Mean value & Standard deviation \\
\hline Tobinq & 0 & 1 & 0.088 & 0.103 \\
\hline$R D$ & 0 & 1 & 0.076 & 0.154 \\
\hline A & 0 & 1 & 0.095 & 0.120 \\
\hline CR & 0 & 1 & 0.086 & 0.124 \\
\hline Growth & 0 & 1 & 0.061 & 0.082 \\
\hline
\end{tabular}

\subsection{Analysis of regression results}

Table 5 shows the regression results of the relationship between technological innovation and company value. Where, the first column shows the regression results whose calculation takes all listed agricultural companies as samples. In columns 2, 3, 4 and 5, according to the combinations of net cash flow generated from the company's operations, investment and financing, the company's life cycle is divided into 4 stages, namely, the start-up stage, the growth stage, the maturity stage and the decline stage.

Table 5. The influence of technological innovation on company value

\begin{tabular}{|c|c|c|c|c|c|}
\hline Variables & Models & Start-up stage & Growth stage & Maturity stage & Decline stage \\
\hline$R D$ & $\begin{array}{c}0.144 * * * \\
(8.08)\end{array}$ & $\begin{array}{l}0.016 \\
(0.35)\end{array}$ & $\begin{array}{c}0.119 * * * \\
(3.69)\end{array}$ & $\begin{array}{c}0.148 * * * \\
(3.74)\end{array}$ & $\begin{array}{c}0.051 \\
(1.69)\end{array}$ \\
\hline$A$ & $\begin{array}{c}0.448 * * * \\
(18.21)\end{array}$ & $\begin{array}{c}0.191 * * \\
(2.38)\end{array}$ & $\begin{array}{c}0.507 * * * \\
(8.94)\end{array}$ & $\begin{array}{c}0.293 * * * \\
(5.10)\end{array}$ & $\begin{array}{c}0.195 * * * \\
(3.97)\end{array}$ \\
\hline
\end{tabular}




\begin{tabular}{|c|c|c|c|c|c|}
\hline \multirow{2}{*}{$C R$} & $\begin{array}{c}0.225^{* * *} \\
(9.47)\end{array}$ & $\begin{array}{c}0.570^{* * *} \\
(5.38)\end{array}$ & $\begin{array}{c}0.279 * * * \\
(4.21)\end{array}$ & $\begin{array}{c}0.255^{* * *} \\
(3.80)\end{array}$ & $\begin{array}{c}0.177^{* * *} \\
(4.09)\end{array}$ \\
\hline \multirow{2}{*}{ Growth } & $0.183^{* * *}$ & $0.357 * * *$ & $0.218^{* * *}$ & $0.267 * * *$ & $0.708^{* * *}$ \\
& $(12.38)$ & $(8.51)$ & $(5.77)$ & $(7.29)$ & $(12.59)$ \\
\hline$R^{2}$ & 0.8690 & 0.8676 & 0.8672 & 0.8766 & 0.8676 \\
\hline
\end{tabular}

Notes: $* * *, * *$ and $*$ indicate that the influence is significant on levels of $1 \%, 5 \%$ and $10 \% . t$ value is shown in brackets.

As can be seen from the first column of Table 5, the regression coefficient between technological innovation and company value is 0.144 , the $t$ value is 8.08 , and significant positive correlation is observed at the level of $1 \%$. It means technological innovation is beneficial to company value increase, the ratio of the regression sum of squares and the total sum of squares of deviations is big, and the model has high goodness of fit. As can be seen from the second column of Table 5, the regression coefficient between technological innovation and the value of companies in start-up stage is 0.016 and no significant correlation is observed. It means in the start-up stage, investment increase in technological innovation does not significantly influence the agricultural company's value. As can be seen from the third column of Table 5, the regression coefficient between technological innovation and the value of companies in growth stage is 0.119 , and significant positive correlation is observed at the level of $1 \%$. It means technological innovation is beneficial to value increase of companies in the growth stage. As can be seen from the fourth column of Table 5, the regression coefficient between technological innovation and the value of companies in maturity stage is 0.148 , the $t$ value is 3.74 , and significant positive correlation is observed at the level of $1 \%$. It means for listed agricultural companies of maturity stage, to increase technological innovation investment can effectively raise their company value. As can be seen from the fifth column of Table 5, the regression coefficient between technological innovation and the value of companies in decline stage is 0.051 and no significant correlation is observed. It means in the decline stage, the agricultural companies' technological innovation does not significantly influence their company value. As to the company's total assets used to measure its size, its liquidity ratio used to measure its solvency, and its operations revenue growth rate used to measure its development ability, they show significant positive correlation with company value in all the four stages, and they are what the companies should lay sustained concern on.

Thus, it can be seen from the research in which the agricultural company technological innovation's influence on its value is studied based on different stages of company life cycle that in the start-up stage, technological innovation investment's influence on company value is not significant. The reason to explain the situation is that agriculture companies in start-up stage lay more concern on survival and aim to increase product sales and market share. At the stage, the $R \& D$ investment which takes up a lot of money is not consistent with the company's development purpose. When the agriculture company enters growth and maturity stages, its technological innovation's positive influence on its value becomes significant. What causes the situation is that in growth and maturity stages, the agricultural company's all aspects including operations and market recognition are relatively stable, which means the company is able to make more investment in R\&D. Also in this stage, R\&D and innovation become the company's needs, because high-level technological innovation can facilitate the company's further movements in market occupation and increase its value. Studying agricultural company samples in decline stage, it is found that their technological innovation has less influence on their value. The author believes that companies at this stage focus on how to quit the market or extend their survival, and they often face declining market demand. Therefore, it is of less significance for the company to invest in technological innovation whose influence on company value also becomes little. In a word, the influence of technological innovation on company value obviously varies when the company is in different life cycle stages.

\section{Robustness test}

In order to make the conclusion more reliable, the company value measurement indicator is changed into return on total assets in this paper, and based on which, the regression analysis is conducted according to the model described in the paper's previous part and the following results are gained. It can be seen from the Table 6 that for all the agricultural samples, $R \& D$ investment is still positively correlated with technological innovation, which is consistent with the previous conclusion. Therefore, the conclusion of this study is robust.

Table 6. Results of robustness test

\begin{tabular}{|c|c|c|c|c|}
\hline Variables & Coef. & Std.Err & $t$ & $P$ \\
\hline$R D$ & 0.133 & 0.022 & 7.38 & 0.000 \\
\hline$A$ & 0.375 & 0.030 & 5.76 & 0.000 \\
\hline CR & 0.255 & 0.039 & 10.34 & 0.000 \\
\hline Growth & 0.240 & 0.017 & 18.94 & 0.000 \\
\hline
\end{tabular}




\section{Conclusion and enlightenment}

This paper takes the agricultural companies listed in China's A-share from 2015 to 2019 as research samples and builds a model to empirically study the influence of technological innovation on company value. Based on the theory of company life cycle, this paper divides sample companies' life cycle into 4 stages, namely, the start-up stage, the growth stage, the maturity stage and the decline stage. The results indicate that in general, technological innovation can increase agricultural company's value. However, such influence varies obviously when the company stays in different stages. When the company is in start-up stage, investment in technological innovation has little influence on its value. When it is in growth and maturity stages, the influence is significant. When it is in decline stage, the influence becomes little again.

Based on the above conclusion, this paper puts forward the following suggestions. First, the company should reasonably allocate its resources. In the growth and maturity stages, the company can have its non-core business outsourced and invest more resources in technological innovation. The companies can also cooperate with each other in research and development to take advantage of each other's strengths. Second, more support should be offered by the government. As a big agricultural country, technological innovation and development in agriculture is of great significance to China's improvement and prosperity. However, the current environment for agricultural companies is not development-friendly, under which agricultural companies suffer from difficult capital turnover, and that reduces the investment put in technological innovation. Therefore, the government should offer more subsides, more support and more favorable policies to technological innovation for agricultural companies. Third, agricultural companies should work with social groups. Technological innovation needs a large amount of investment in the early stage, and it also takes a longer time to produce outcomes in the stage, which means a great deal of pressure. In this case, if cooperation can be carried on between the company and social groups such as academic research institutions, the R\&D costs can be reduced and disadvantages can be made up for. Fourth, the stock market can be used to bring more channels of capital sources for agricultural companies. Compared with the number of listed companies in other industries, the one of agriculture is significantly smaller. Therefore, listing standards set for agriculture companies should be appropriately lowered to create more sources of capital for them. Fifth, try to attract more investors. At present, investment in agricultural companies is insufficient. Therefore, more investment should be attracted to the development of excellent agricultural companies. This can be done through the company's efforts in publicity and the government's policy guidance.

\section{Acknowledgments}

This paper is one of the periodic results of the national college students' innovation training project Research on the Relationship between Semi-mandatory Bonus Policy and Enterprise Value Based on Life Cycle (202010294042).

\section{References}

1. W.D. Guth. (1990). Guest editor's introduction: Corporate entrepreneurship [J]. Strategic Management Journal (11): 5-15.

2. Z. Grilliches. (1981). Market value, R\&D and patents [J]. North-Holland 7 (2): 183-187.

3. I.C. Ehie, K. Olibe. (2010). The effect of R\&D investment on firm value: An examination of US manufacturing and service industries[J]. International Journal of Production Economics, 128(1): 127-135.

4. H.W. Cheng, Y.H. Zhang, Y. Chang. (2006). An empirical study on the correlation between corporate R\&D investment and performance. Scientific Management Research (3): 110-113.

5. W.G. Xie. (2017). Innovation investment, ownership structure and company value $[\mathrm{J}]$. Communication of Finance and Accounting (12): 93-97.

6. [6] W. Wang, J.Y. Wu, P.F. Zhang. (2016). Research on government subsidy, R\&D investment and value of IT companies [J]. Science \& Technology Progress and Policy 33 (22): 86-91.

7. L. Wang, P.X. Liu, P.L. Shen. (2020). Research on cumulative effect of $R \& D$ investment, abnormal return and company value $[\mathrm{J}]$. Journal of Industrial Technological Economics 39 (07): 48-55.

8. V. Dickinson. (2011). Cash Flow Patterns as a Proxy for Firm Life Cycle [J]. The Accounting Review 86 (6): 1969-1994. 